\title{
RONGGENG PASAMAN: DOKUMENTASI PEMENTASAN GANTO PASAMAN
}

\author{
Dewiati $^{1^{*}}$, Eka Meigalia ${ }^{2}$ Pramono $^{3}$ \\ dati5801@gmail.com* \\ Fakultas Ilmu Budaya Universitas Andalas ${ }^{1,2,3}$
}

\begin{abstract}
ABSTRAK
Artikel ini adalah hasil dokumentasi ronggeng Pasaman grup Ganto Pasaman yang ada di Kecamatan Bonjol. Metode yang digunakan adalah kualitatif. Data diperoleh melalui wawancara dengan informan, observasi, dan pengamatan langsung saat pertunjukan. Selain itu data tambahan diperoleh dari buku dan hasil penelitian yang terkait dengan penelitian ini.

Ronggeng grup Ganto Pasaman adalah salah satu bentuk sastra lisan Minangkabau yang dipertunjukkan dengan cara menggabungkan keahlian berpantun dan menari dalam satu pertunjukan dan diiringi oleh musik yang dimainkan oleh sepuluh orang. Ronggeng biasanya dipertunjukkan dalam acara ulang tahun Kabupaten Pasaman, acara-acara pemberian gelar, acara perhelatan perkawinan dan lain-lain. Teks yang digunakan adalah pantun, jenis pantun yang dibawakan adalah pantun muda-mudi, isi pantun biasanya berkaitan dengan perasaan rindu, dendam, kesedihan, gurauan, pengajaran, norma-norma dan lain-lain.
\end{abstract}

Kata kunci: Ronggeng Pasaman, Ganto Pasaman, Sastra Lisan, Dokumentasi

\section{RONGGENG PASAMAN: PERFORMANCE DOCUMENTATION OF GANTO PASAMAN}

\begin{abstract}
This article is the documentation of the Ganto Pasaman group ronggeng Pasaman in Bonjol District. The qualitative data method is obtained through interviews with informants, observation, and direct observation during the performance. Besides, additional data were obtained from books and research results related to this study.

Ronggeng Ganto Pasaman group is a form of Minangkabau oral literature that combines singing and dancing skills in one performance and is accompanied by ten people's music. Ronggeng is usually performed in Pasaman Regency birthdays, ceremonies for awarding titles, wedding ceremonies, etc. The text used is the rhyme. The type of rhyme that is performed is the young rhyme. The rhyme's content is usually related to feelings of longing, resentment, sadness, jokes, teaching, norms, and so on.
\end{abstract}

Keywords: Ronggeng Pasaman, Ganto Pasaman, Oral Tradition, Documentation 


\section{PENGANTAR}

Sastra lisan berarti sastra yang disampaikan secara lisan dan diwariskan secara turun-temurun dari mulut ke mulut. Fungsi sastra lisan adalah untuk hiburan, salah satu tempat persebaran sastra lisan yaitu di Pasaman, sastra lisan yang berkembang di Pasaman sangat banyak. Menurut Amir dkk, (2006: 128-150) sastra lisan yang berkembang di Pasaman adalah ronggeng pasaman, bakobar, rantak kudo, ratok bagindo suman, iriak onjai. Sebagian besar sastra lisan tersebut sudah hilang, seperti pada sastra lisan iriak onjai. Sastra lisan iriak onjai ini sudah hilang karena masyarakat Pasaman tidak lagi memanen padi dengan cara iriak onjai tetapi telah menggunakan mesin.

Kondisi berbeda terjadi pada Ronggeng Pasaman, Ronggeng Pasaman merupakan sastra lisan yang menggabungkan keahlian berpantun dan menari pada pertunjukannya dengan diiringi musik berirama Melayu. Pantun merupakan unsur penting dalam sastra lisan yang satu ini karena didendangkan atau dinyanyikan oleh seorang penampil 'wanita' atau "ronggeng" sambil berjoget mengikuti irama lagu. Dengan demikian, penyebutan kata 'ronggeng' mengacu pada dua pengertian, yaitu ronggeng sebagai satu bentuk seni pertunjukan dan 'ronggeng' sebagai sebutan untuk pelaku (penampil) 'wanita' yang ahli dalam berpantun (Meigalia, 2013: 6).

Ronggeng Pasaman saat ini masih ada, meskipun di beberapa tempat sudah tidak ditemukan lagi. Seperti di Bonjol, Ronggeng Pasaman hanya terdapat satu grup ronggeng yaitu grup Ganto Pasaman. Menariknya grup ini cukup aktif, hal ini dibuktikan dengan seringnya grup ini tampil di berbagai acara, seperti di acara ulang tahun Kabupaten Pasaman, acara-acara pemberian gelar, acara perhelatan perkawinan dan lain-lain. Setidaknya dalam satu bulan grup Ganto Pasaman tampil sebanyak 4-7 kali tergantung banyaknya pesta perkawinan atau acara-acara lainnya.

Dari segi pertunjukan dan pantun yang didendangkan, grup Ganto Pasaman mempunyai nada atau irama yang berbeda dengan Ronggeng lainnya. Hal ini dikarenakan, nada atau irama pantun yang dinyanyikan grup Ganto Pasaman lebih meriah dan bersemangat didengar penonton saat pertunjukannya daripada Ronggeng Pasaman pada umumnya. Pantun yang digunakan dalam pertunjukan ini secara spontan, pantun disampaikan dengan menggunakan dialek daerah setempat. Personil grup Ganto Pasaman terdiri dari laki-laki yang berusia kira-kira 30-50 tahun. Hingga saat ini, belum ada pewaris atau genarasi muda di Bonjol yang tertarik untuk beronggeng. Maka penelitian ini perlu dilakukan untuk mendokumentasikan satu-satunya grup Ronggeng yang ada di Bonjol.

Berdasarkan latar belakang di atas, masalah yang dirumuskan adalah bagaimanakah bentuk pertunjukan Ronggeng Pasaman dalam grup Ganto Pasaman?

\section{KERANGKA TEORI DAN METODE}

Amir (2013: 75-78) menyatakan bahwa sastra lisan berarti sastra yang disampaikan secara lisan, jika disampaikan secara lisan maka diterima juga secara lisan. Sastra lisan dibawakan atau ditampilkan oleh seniman sastra lisan, sastra lisan merupakan suatu dunia yang lapang yang melibatkan banyak orang, dunia banyak orang dalam arti kata sebenarnya. Ciri-ciri sastra lisan adalah: ada wujudnya dalam pertunjukan dalam banyak kasus diiringi dengan 
instrumen bunyi-bunyian bahkan tarian. Unsur hiburan dan pendidikan dominan di dalamnya. Menggunakan bahasa setempat, bahasa daerah, paling tidak dialek daerah.

Unsur-unsur yang terkait dalam sastra lisan menurut Amir (2013: 83-141) adalah pertunjukkan, penampil, teks dan penggubahnya, dan khalayak. Dalam unsur pertunjukkan terdapat aspek suasana, waktu, tempat dan situasi pertunjukkan. Ada suasana formal, misalnya pertunjukan salawat dulang untuk memperingati Maulud Nabi ; terlebihlebih dilaksanakan di surau, pada suasana demikian, semua orang menjaga sikap tidak ada yang bersorak, sebaliknya bila pertunjukan dilakukan untuk berhibur, seperti masa panen, bagurau semua orang bergembira ria karena ini adalah suasana yang rileks atau tidak resmi, pada suasana seperti ini khalayak bisa bersikap agak bebas, kadang bersorak, bahkan menari.

Waktu adalah kesempatan yang menjadi alasan pertunjukan sastra lisan, sastra lisan pada umumnya dipertunjukkan pada malam hari, sastra lisan sendiri adalah hiburan malam hari bagi anggota masyarakatnya setelah lelah bekerja siang hari, yang bermakna rentang waktu pertunjukan ada yang semalam suntuk, ada yang beberapa malam, ataupun beberapa jam saja, itulah sebabnya khalayak sastra lisan secara umum adalah laki-laki. Tempat untuk pertunjukan sastra lisan ditentukan dan disetujui bersama oleh khalayaknya, tempat ini berhubungan dengan nilai dianut khalayak pemilik suatu sastra lisan, artinya ada genre yang disetujui khalayaknya dipertunjukkan di beberapa tempat seperti di tanah lapang, di kedai minum, di rumah penduduk. Situasi yang timbul adalah dari alasan menyelenggarakan pertunjukan sastra lisan tersebut.

Penampil adalah orang-orang yang menyuguhkan sastra lisan dalam suatu pertunjukan. Proses belajar seorang penampil sastra lisan adalah di mana proses belajar itu dimulai dengan pengenalan melalui pertunjukanpertunjukan, pertunjukan demi pertunjukan membawa mereka terbiasa dan memperoleh kepandaian pada tahap pertama. Tahap kedua mulai ketika ia telah dapat berdendang dengan atau tanpa alat bunyi-bunyian (instrument) di hadapan orang lain. Kalau untuk berguru seseorang harus memberi syarat berguru kepada gurunya, yaitu memberi kain putih, ayam biriang, pisau, beras, dan uang. Masa berguru diakhiri dengan upacara dan ditandai dengan pemberian ayam hitam dari murid kepada gurunya. Jenis kelamin penampil sastra lisan biasanya laki-laki. Keadaan itu dapat dipahami karena pertunjukan sastra lisan diselenggarakan malam hari. Kalau dilihat dari status sosial seniman atau penampil sastra lisan umumnya berpendidikan rendah, karena para seniman itu sudah bisa dikatakan tua dan pada umunnya berpendidikan rendah.

Teks dan penggubahannya adalah bagian khusus dari sebuah tradisi lisan. Tekslah yang membawakan puitika dan estetika yang mereka miliki bersama. Teks pula yang menjadi penengah komunikasi sastra di antara penampil dan khalayak. Tentang transkripsi teks, pengalihan dari kaset atau audio ke tulisan. Ada beberapa kemungkinan teknik penulisan transkripsi. Pertama, mentranskripsikan begitu saja semua bunyi lisan (artinya dari alat ucap penampil) yang didengar. Kedua, mentranskripsi bunyi lisan yang didengar lalu menandai mana yang teks sebenarnya, mana yang bunyi-bunyi pengimbuh. Pilih ketiga, mengambil teks yang diperkirakan menurut kata dan atau kalimat yang benar saja, tidak memasukkan bunyi-bunyi pengimbuhan.

Orang yang datang ke tempat pertunjukan sastra lisan adalah khalayak yang biasanya merupakan para pecinta sastra lisan, terutama masyarakat bahasa sastra itu karena sastra lisan diucapkan dalam bahasa daerah. Hal ini 
merupakan situasi yang umum, akan tetapi dalam masyarakat ada nilai tersendiri untuk datang dan tidak datang ke tempat pertunjukan. Tujuan khalayak datang ke tempat pertunjukan sastra lisan karena mencari hiburan dan mencari kepuasan estetis, seperti pertunjukan permainan-permainan rakyat dan pertunjukan sastra lisan.

Metode yang dipakai dalam penelitian ini adalah metode kualitatif yang akan dilakukan dengan dua cara. Pertama, pendokumentasian dalam bentuk deskripsi. Membuat deskripsi dalam sebuah pertunjukan tentu memiliki masalah yang lumrah ditemukan, karena sebuah pertunjukan yang bersifat satu kali tersebut seakan-akan hanya dapat bisa diambil menggunakan alat rekam, termasuk juga rangkaian kata-katanya. Akan tetapi di sisi lain, ketika pengabadian sebuah pertunjukan selesai dilakukan, baik menggunakan alat rekam, audio visual, foto, maupun deskripsi kata-kata, pertunjukan tersebut juga telah berakhir. Pertunjukan tersebut selamanya telah berakhir namun rekamannya (meskipun dengan kekurangannya) masih bisa disaksikan oleh siapa pun dan kapan pun sesuai kehendak (Pudentia, 2007: 40).

\section{HASIL DAN PEMBAHASAN}

Ronggeng Pasaman merupakan kesenian tradisional yang di sampaikan secara lisan dan dimainkan dengan cara menggabungkan keahlian berpantun dan menari dalam satu pertunjukan dan diiringi oleh musik. Penari atau pemain Ronggeng terdiri dari sepuluh orang, enam pemain musik dan empat penari yang menari sambil bernyanyi bergiliran.

Menurut Jonnedi (dalam Gusmanto 2016) Tradisi lisan ini pada mulanya berasal dari orang-orang Jawa, Minang, dan Mandailing yang di penjara pada masa penjajahan Belanda di daerah Pasaman. Mereka menghibur diri dengan menari dan memukul belek (kaleng kerupuk) sambil bernyanyi dan menari. Nama Ronggeng itu dulunya adalah guguah belek (memukul kaleng), Kesenian ini mulai dikenal Ronggeng Pasaman ketika bangsa Jepang menyumbangkan seperangkat alat berupa biola dan sepasang gendang.

Etnis Jawa tidak banyak mempengaruhi bahasa ataupun tradisi yang ada di Pasaman, namun berbeda dengan tradisi sastra lisan yang satu ini, dari namanya saja sudah menarik karena kita kalau mendengar namanya pasti mengingatkan kita pada satu seni tradisi dari Jawa yaitu Ronggeng. Kalau nama tradisi yang berkembang di Pasaman dikenal dengan nama Ronggeng Pasaman itulah yang membedakannya dari Ronggeng yang terdapat di Jawa.

Ronggeng di daerah Jawa merupakan salah satu tradisi yang berhubungan dengan ritual atau upacara kesuburan. Upacara ini dilakukan supaya hasil pertanian warga melimpah-ruah. Karena terkait dengan kesuburan inilah, gerakan dalam tarian yang dilakukan oleh penari perempuan (ledhek) dengan penari laki-laki (pengibing) ini, mirip gerakan orang yang sedang bercinta. Tarian tersebut memang terlihat erotis, tapi saat itu tariannya tak lebih dari sekadar melambangkan kesuburan saja (Enanto, dalam Zuriati, 2008).

Ronggeng Pasaman sebagai sebuah seni tradisi yang mempunyai fungsi sebagai hiburan atau sebagai pelipur lara. Seni tradisi ini biasanya dipertunjukkan pada malam hari, mulai setelah salat isya sekitar pukul sepuluh malam sampai pagi menjelang subuh (kira-kira pukul lima pagi). Tempat pertunjukan biasanya di lapangan terbuka atau di 
pentas yang dibuat khusus untuk pertunjukan dan dipertunjukkan dalam pesta perkawinan atau dalam acara adat lainnya.

Pada saat ini Ronggeng Pasaman masih bisa ditemukan yaitu salah satunya di daerah Bonjol, Nagari Ganggo Hilia Kecamatan Bonjol. Di daerah ini terdapat satu grup yang bernama grup Ganto Pasaman, di mana grup ini adalah satu satunya grup yang masih aktif sampai pada saat sekarang ini, walaupun zaman semakin modern tetapi grup ini tidak melupakan atau meninggalkan tradisi lisan yang sudah lama berkembang di daerahnya tersebut.

Awal mula sejarah dari nama grup Ronggeng Ganto Pasaman adalah diambil dari kata Ganto (genta). Ganto adalah sejenis mainan yang ada di leher sapi, dan mempunyai atau menghasilkan bunyi yang sangat berdering atau sangat lantang, makna dari Ganto tersebut yaitu supaya tradisi Ronggeng ini dering atau bunyinya kuat dan bisa didengar dan dikenal sehingga tradisi ini tidak hilang ditelan masa. Dan Pasaman adalah nama dari tempat lahir dan berkembangnya tradisi ini, jadi nama grup Ronggeng Ganto Pasaman mempunyai makna dan tujuan di mana pun ronggeng ini dipertunjukkan dan dimainkan supaya Ronggeng ini dikenal banyak orang karena bunyi Ronggeng ini sangat keras dan bersemangat jadi siapa pun yang mendengarnya pasti akan ikut berjoget atau menari.

Dalam pertunjukkannya Grup Ronggeng Ganto Pasaman biasanya menyanyikan atau membawakan lagu di awal pertunjukkan dengan nada atau tempo biasa yang belum terlalu meriah atau semangat, dan seterusnya makin lama makin malam nyanyian yang dibawakan akan mengalami perubahan ke yang lebih semangat dan menggunakan tempo yang lebih cepat sehingga penonton tidak mengantuk dan penonton atau khalayak larut dalam pertunjukkan walaupun hari sudah mulai pagi.

Biasanya pertunjukkan Grup Ronggeng Ganto Pasaman dimainkan pada malam hari sesudah salat isya hingga menjelang masuknya waktu subuh. Akan tetapi tidak menutup kemungkinan pertunjukan Grup Ronggeng Ganto Pasaman dilaksanakan dalam beberapa jam saja, tergantung permintaan dari tuan rumah, berarti lagu yang dibawakan dari awal mulai pertunjukkan tersebut langsung menggunakan tempo cepat. Berhubung mereka main hanya sebentar dan tidak mau mengecewakan tuan rumah yang sudah mengundang Grup ini.

Selanjutnya dimainkan pada acara nyalan mandan, yang dimaksud adalah marapulai (mempelai pria) dan anak daro (mempelai wanita) diarak dan didudukkan di atas kursi. Sebagai gagang untuk di pegang atau diangkat oleh para sumando, yang diarak-arak langsung menuju ke rumah orang tua marapulai. Lagu yang dibawakan pada saat arak-arakan menggunakan tempo yang cepat dan keras, tiba di rumah orang tua ditambah dengan pertunjukkan silek sonsong antara tuan rumah berlawanan dengan yang mengantar marapulai dan anak daro tadi. Pertunjukkan arakarakan ini dilakukan pada siang hari sesudah salat zuhur sampai salat magrib.

Grup Ronggeng Ganto Pasaman biasanya dipertunjukkan pada acara adat perkawinan, sunat rasul, acaraacara adat pemberian gelar pusaka, acara ulang tahun Kabupaten Pasaman, dan upacara adat lainnya.

Mengenai keberadaan Grup Ronggeng Ganto Pasaman di Nagari Ganggo Hilia pada saat ini, ada sepuluh orang anggota pemain yang merupakan para penggiat seni yang masih aktif sampai sekarang, sepuluh orang pemain ini berasal dari beberapa kejorongan yang terdapat di daerah Ganggo Hilia. Dulunya para pemain tersebut punya grup juga di kejorongannya masing-masing, namun makin hari makin majunya kebutuhan masyarakat terhadap kesenian 
yang lebih aktif, dan efeknya pada kesenian Ronggeng ini kurang diminati bahkan tidak diminati oleh kalangan masyarakat yang ada di Ganggo Hilia.

Kurangnya peminat masyarakat pada kesenian Ronggeng membuat grup ini tidak ada generasi penerusnya, dengan demikian pewaris yang tersisalah yang akan bertanggung jawab untuk melanjutkan dan melestarikan kesenian Ronggeng. Tidak hanya itu, keberadaan orgen tunggal pada saat ini sangat mempengaruhi kesenian Ronggeng, banyak masyarakat lebih memilih orgen tunggal dari pada ronggeng.

Pakaian atau kostum adalah salah satu hal yang wajib dalam pertunjukkan Ronggeng, pakaian yang dikenakan pada pertunjukkan Ronggeng adalah pakaian yang sopan dan bernuansa Islam. Semua anggota kecuali peronggeng memakai baju seragam seperti baju batik atau baju randai, dan memakai celana goyang. Sebagai pelengkap dalam pertunjukkan Ronggeng, salendang (selendang) diletakkan di leher. Peronggeng memakai baju perempuan yang bentuknya menyerupai baju kurung tapi memakai manik- manik, sanggul, dan tak ketinggalan juga mamakai salendang tapi dijadikan hijab.

Pertunjukkan atau permainan Ronggeng yang dilakukan di setiap acara menggunakan pakaian yang sama untuk peronggeng sendiri, tetapi beda halnya dengan pemain yang lain menggunakan baju batik yang bernuansa Islam pada saat acara perkawinan dan pada saat acara nyalan Mandan menggunakan baju randai. Salah satu hal yang wajib dipakai dalam pertunjukkan Ronggeng adalah salendang. Salendang ialah hal yang tidak boleh ditinggalkan dalam pertunjukkan Ronggeng. Semua pakaian digunakan atau dipakai pada saat pertunjukan Ronggeng dipertunjukkan pada acara adat perkawinan, sunat rasul, acara-acara adat pemberian gelar pusaka, acara ulang tahun Kabupaten Pasaman, dan upacara adat besar lainnya.

Grup Ronggeng Ganto Pasaman yang berada di Kenagarian Ganggo Hilia memang memiliki perbedaan dengan Ronggeng pada umumnya di Kabupaten Pasaman dan Kabupaten Pasaman Barat. Perbedaannya terdapat pada pantun dan juga pada alat musik yang digunakan pada saat dimainkan atau dipertunjukan. Alat musik yang dimainkan menggunakan alat-alat seperti biola, gendang atau tambua, giring-giring, dan botol minum bekas.

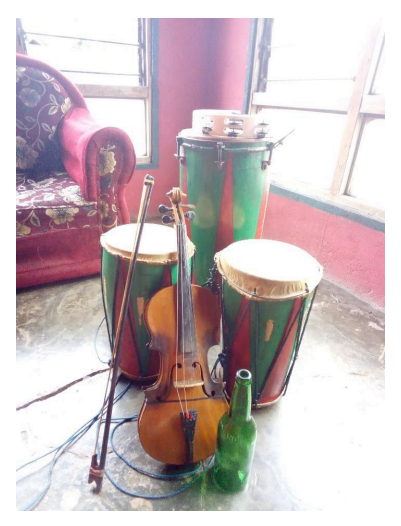

GAMBAR 1. Alat musik yang digunakan.

Sebelum pertunjukan Ronggeng dimulai, tuan rumah diminta agar menyiapkan syarat-syarat sebelum berlangsungnya pertunjukan. Biasanya yang diminta oleh anggota grup Ronggeng adalah seperti minuman tradisional 
(tuak) salah satu hal yang wajib tuan rumah sediakan. Dan sebelum pertunjukan dimulai semua anggota grup ganto pasaman dipersilahkan memakan lamang (ketan panggang) dan air putih yang telah dihidangkan dan diletakkan di atas meja dekat tempat pertunjukan Ronggeng yang akan ditampilkan.

Semua anggota Ronggeng makan dan minum kecuali yang akan menjadi peronggengnya karena dia harus bersiap terlebih dahulu, memakai kostum dan harus berhias seperti perempuan. Peronggeng dibantu oleh perias pengantin. Tidak menutup kemungkinan kalau keadaan mendesak, sang peronggeng berhias sendiri karena secara tidak langsung sang peronggeng tahu sedikit banyaknya tentang alat-alat yang digunakan oleh penghias untuk menghias dirinya. Sang peronggeng memakai kostum atau baju yang berbeda dari anggota lain. Sang peronggeng juga memakai sandal yang bertumit dan tidak memakai sepatu seperti anggota lainnya. Bisanya peronggeng sebelum di hias sudah minum tuak untuk menghilang sedikit rasa malu karena berpenampilan seperti itu.

\section{Suasana Pertunjukan}

Mereka yang datang menonton hanya sedikit yang duduk di atas kursi yang disediakan oleh tuan rumah. Laki-laki dan perempuan ikut menari baik di pentas pertunjukan dan di luar pentas pertunjukan. Tidak terkecuali anakanak meskipun acara pertunjukan Rongeng suasananya bukan untuk anak-anak namun mereka ikut menari dan bernyanyi. Anak-anak yang hadir menyaksikan pertunjukan Ronggeng tidak sampai acara selesai hanya sampai jam 23:00 WIB karena khalayak anak-anak bersekolah pada pagi harinya maka ibu atau bapak mereka membawa anakanak mereka pulang, setelah mereka mengantar anak-anaknya mereka kembali lagi ke tempat pertunjukan Ronggeng. Acara Ronggeng berjalan begitu meriah yang diiringi musik, nyanyi dan tari-tarian, biasanya pertunjukan Ronggeng akan berakhir pada jam 03:00 atau sebelum subuh.

2. Waktu Pertunjukan

Sebagai sastra lisan, ronggeng berfungsi sebagai pelipur lara atau hiburan. Biasanya, ronggeng dipertunjukkan pada malam hari, mulai pukul 22.00 WIB sampai pagi menjelang Subuh (Amir dkk 2006:130). Waktu ini dipilih bertujuan agar tidak merusak suasana beribadah. Waktu penampilan tidak selalu demikian, tergantung pada orang yang mengundang grup Ronggeng tersebut, lama waktu pertunjukan Ronggeng ini juga ditentukan oleh suasana yang ada pada saat itu, semakin bergairah pertunjukan ronggeng maka semakin lama pertunjukan berlangsung dan apabila suasananya kurang menarik maka acara akan cepat selesai. Cuaca pun sangat berpengaruh misalnya seperti hujan, angin kencang dan lain sebagainya dapat membatasi lamanya waktu pertunjukan.

Pada saat pertunjukan Ronggeng biasanya ada yang satu jam pertunjukan tiga jam pertunjukan, satu malam dan satu malam suntuk tergantung permintaan tuan rumah, dan tergantung situasi kondisi pada saat itu. Pertunjukan Ronggeng grup Ganto Pasaman di acara perkawinan yang penulis ambil sebagai objek penelitian, pertunjukan Ronggeng dimulai pada jam 21:00 WIB sampai jam 03:00 WIB Subuh. Karena waktu Subuh akan masuk dan acara atau pertunjukan Ronggeng diberhentikan. Karena suasana pertunjukan Ronggeng sangat meriah maka pertunjukan Ronggeng berlangsung lama, akan tetapi karena cuaca tidak mengizinkan karena hujan maka pertunjukan Ronggeng cepat selesai dan tidak dilanjutkan kembali, akibat hujan tempat pertunjukan basah dan tidak memungkinkan untuk dilanjutkannya pertunjukan Ronggeng. 


\section{Tempat Pertunjukan}

Menurut Amir dkk. ( 2006:130), tempat pertunjukan ronggeng biasanya ditampilkan pada acara yang diadakan dalam rangka merayakan hari raya Idul Fitri dan Idul Adha. Kalau di daerah Bonjol Ronggeng di pertunjukan biasanya dipertunjukkan pada acara adat perkawinan, sunat rasul, acara-acara adat pemberian gelar pusaka, acara ulang tahun Kabupaten Pasaman, dan upacara adat dan pada pesta-pesta lainnya yang telah menyiapkan tempat berlangsungnya pertunjukan ronggeng. Tempat yang disediakan adalah tempat yang nyaman dan tentunya luas dan dapat memuat banyak penonton yang berdatangan untuk menyaksikan pertunjukan ronggeng. Biasanya tempat-tempat yang digunakan untuk menampilkan pertunjukan ronggeng seperti halaman rumah dan di lapangan terbuka, kadang ada juga tuan rumah menyediakan semacam pentas untuk itu.

4. Waktu dan Situasi

Berkenaan situasi pertunjukan Ronggeng, karena ditampilkan pada acara perkawinan dan bertujuan untuk menghibur maka semua orang bergembira dan bersikap bebas seperti ada yang bernyanyi dan menari selama tidak melanggar norma-norma adat dan agama. Sebelum pertunjukan Ronggeng dimulai situasi yang ada di lapangan, awalnya dihadiri oleh anak-anak dan para remaja laki-laki maupun perempuan karena mereka sangat antusias sekali untuk melihat pertunjukan Ronggeng.

Selain acara pernikahan dan adat, Rongeng juga dipertunjukkan dalam acara formal seperti acara Hut Kab. Pasaman yang dihadiri oleh para pejabat daerah, mereka yang berstatus sebagai pegawai pemda Pasaman tidak canggung langsung terlibat menari dan bernyanyi bersama khalayak banyak yang berasal dari berbagai kalangan. Ronggeng adalah pertunjukan sastra lisan yang tidak mengenal status sosial di dalamnya terbukti siapa pun bisa hadir dan menyaksikan dan terlibat di dalam pertujukkan Ronggeng. Status sosial dalam pertunjukan Ronggeng seakan hilang.

\section{Syarat dan Proses Belajar Grup Ronggeng Ganto Pasaman}

Di dalam grup Ronggeng Ganto Pasaman sebenarnya tidak ada syarat-syarat khusus bagi pemuda atau anakanak yang ingin menjadi anggota dalam grup ini, berdasarkan mendapat salah seorang tetua dalam grup Ronggeng tersebut tidak ada aturan tertulis, berdasarkan wawancara dengan beberapa anggota grup Ronggeng Ganto Pasaman, mereka memberikan penjelasan sebagai berikut. Menurut pengalaman pak Muris, dia mulai tertarik pada Ronggeng sejak umur 15 tahun, dulunya belajar secara otodidak, dengan cara hadir dan menonton pada saat pertunjukan Ronggeng diadakan di Bonjol maupun di daerah lain, pak Muris selalu datang pada pertunjukan Ronggeng dan beliau sangat tertarik sekali serta ingin mencoba atau mempraktikkan yang selama ini dilihat dan dia dengar, karena itu adalah salah satu hobi pak Muris, dan sampai sekarang pak Muris aktif.

Menurut Sijon (41 tahun) mengatakan bahwa siapa saja yang ingin menjadi anggota dari grup ini boleh saja ikut di setiap kali pertunjukan atau dimainkannya Ronggeng ini, sebenarnya tergantung dari niat kita, kalau kita mau menjadi anggota dan mau mempelajari tradisi lisan ini, sementara masyarakat yang ada di sekeliling kita banyak yang telah meminggirkan kesenian tersebut atau telah menurun kepeduliannya, karena ini disebabkan oleh semakin 
majunya teknologi dan pengaruh globalisasi sehingga membuat nilai-nilai dan makna yang terkandung di dalam sebuah kesenian tradisi menjadi semakin menghilang.

Menurunnya minat masyarakat terhadap Ronggeng Pasaman terutama para kawula muda yang seharusnya menjadi penerus untuk mengembangkan kesenian tradisional Ronggeng Pasaman tersebut membuat para seniman Ronggeng memutar otak untuk menarik kembali minat kaum muda terhadap Ronggeng Pasaman tersebut. Dengan berubahnya minat masyarakat terhadap kesenian Ronggeng Pasaman para seniman Ronggeng mulai mencari solusi untuk meningkatkan kembali minat masyarakat terhadap Ronggeng Pasaman khususnya pada Grup Ronggeng Ganto Pasaman.

Seni pertunjukan tradisional seperti Ronggeng ini dipandang hanya sebagai hiburan untuk masyarakat, padahal banyak nilai-nilai yang terkandung di dalamnya, selain itu masyarakat lebih terhadap kesenian luar dibandingkan dengan kesenian daerahnya. Sehingga akhirnya kesenian tradisional mendapat tantangan besar supaya mampu dan tetap bisa bertahan di tengah-tengah masyarakat.

\section{Laki-laki dan Perempuan}

Dalam pertunjukan sastra lisan jenis kelamin sangat berpengaruh sekali, seperti yang kita ketahui perempuan sangat tabu keluar pada malam hari berhubung penampilan sastra lisan seperti Ronggeng diadakan pada malam hari. Perempuan tidak diperbolehkan keluar hanya dengan alasan untuk menonton pertunjukan sastra lisan atau kesenian lainnya, perempuan harus berada di rumah pada malam hari untuk mendampingi anak-anaknya, menjaga anakanaknya dan melakukan pekerjaan rumah. Karena pertunjukan Ronggeng ditampilkannya pada malam hari jadi dapat disimpulkan bahwa semua penampil atau anggota Ronggeng adalah laki-laki. Laki-laki menggantikan peran perempuan dalam pertunjukan Ronggeng, laki-laki di dandani seperti perempuan, mulai dari berbaju kurung, berkain kodek dan memakai selendang layaknya perempuan sebenarnya, sampai ke wajah akan dibuat seperti wanita, di make up seperti perempuan.

Sikap seperti itu masih berlaku sampai sekarang dalam pertunjukan Ronggeng, mereka tidak memperbolehkan perempuan tampil dan menjadi tontonan khalayak banyak pada malam hari, karena begitu sejak dahulunya adat di Minangkabau menghormati dan memperlakukan perempuan.

\section{Status Sosial}

Semua anggota Rongeng grup Ganto Pasaman umumnya berpendidikan rendah dan hanya beberapa anggota saja yang tamat sekolah menengah atas, ada yang tidak tamat sekolah dasar dan ada juga yang tidak sekolah, bisa dikatakan kalau anggota Roggeng grup Ganto Pasaman adalah orang biasa dan tidak dari kalangan kelas sosial yang lebih tinggi dari masyarakat pada umumnya.

\section{Khalayak/ penonton}

Pertunjukkan Ronggeng sangat berpengaruh sekali terhadap kehadiran penonton atau khalayak. Biasanya khalayak dapat meminta pemain ronggeng menyanyikan pantun kesukaannya, bahkan ada juga khalayak yang ikut menyumbangkan suaranya untuk melantunkan pantun-pantun yang disukainya. Khalayak yang demikian tentu saja 
mempunyai keberanian dan pandai menyanyikan pantun-pantun tersebut dan ini kebanyakan dari penonton yang tuatua. Menurut Amir dkk. (2006:131) sastra lisan ronggeng ini masih diminati oleh masyarakat pendukungnya, baik tua, maupun anak-anak. Namun, ada sebagian masyarakat dari golongan tua (alim ulama) yang tidak setuju dengan anak rongeng, karena kurang sesuai dengan Islam, terutama dalam hal laki-laki berpakaian wanita.

Tujuan khalayak menyaksikan pertunjukkan Ronggeng adalah untuk mencari hiburan dan kesenangan, menurut Amir (2013:139) ketika sastra lisan dipandang sebagai hiburan, khalayak datang untuk memperoleh, kepuasan estetis, dan kesenangan, akan tetapi, sesungguhnya tidak berhenti di sana. Dalam sastra lisan tersimpan pelajaran/teladan. Secara umum dapat dikatakan bahwa dalam sastra lisan terkandung amanat pendidikan dan pengajaran, itulah sebabnya khalayaknya mau menyelenggarakan suatu pertunjukan dengan menyelenggarakan pertunjukan, khalayaknya sudah maklum risiko yang harus ditanggung, misalnya menyediakan tempat, menyediakan makanan, dan menyediakan uang lelah untuk penampil. Dengan menyelenggarakan dan mendukung penyelenggaraan, berarti khalayak sastra lisan telah mendukung keberadaan sastra lisan. Dapat dibayangkan bila khalayaknya tidak mau lagi menyelenggarakan pertunjukan, sastra lisan akan punah.

\section{PENUTUP}

Ronggeng Ganto Pasaman merupakan kesenian tradisional yang disampaikan secara lisan dan dimainkan dengan cara menggabungkan keahlian berpantun dan menari dalam satu pertunjukan dan diiringi oleh musik. Penari atau pemain Ronggeng terdiri dari sepuluh orang, enam pemain musik dan empat penari yang menari sambil bernyanyi bergiliran. Personil Grup Ronggeng Ganto Pasaman terdiri dari laki-laki yang berusia kira-kira 30-50 tahun, yang terdiri dari 10 orang, hanya merekalah yang masih memainkan pertunjukan tradisi lisan ini hingga sekarang. Bila di waktu yang akan datang tidak ada generasi yang baru dan lebih muda, maka bisa jadi Ronggeng di Kecamatan Bonjol mati atau punah.

Grup Ronggeng Ganto Pasaman tidak memiliki aturan-aturan khusus dalam setiap penampilannya. Tidak memberatkan setiap pemain, atau penonton dalam setiap pertunjukannya. Siapa pun yang ingin belajar atau ingin menikmati pertunjukan Ronggeng dipersilahkan dengan senang hati. Pada pertunjukan Ronggeng, Seorang pemain dapat melakukan perbedaan pada teks-teks pantun. Perbedaan itu dapat terjadi karena faktor si pemain maupun masyarakat yang menikmati cerita tersebut. Tidak ada teks pantun dari pertunjukan yang persis sama. Oleh karena itu, ada bagian teks pantun yang ditambah, diubah, atau dikurangi sehingga terjadi perbedaan antara satu pemain dengan pemain yang lain.

\section{REFERENSI}

Amir, Adriyetti, dkk. 2006. Pemetaan Sastra Lisan Minangkabau. Padang. Andalas University Press.

Amir, Adriyetti. 2013. Sastra Lisan Indonesia.Yogyakarta: CV Andi Offsett

Delmalia. 2015. "Kesenian Ronggeng Group Senandung Rindu di Kecamatan Gunung TulehKabupaten Pasaman Barat". Pasaman Barat: Jurnal Humanus Vol.XIV No.2 Th. 2015.

Fernando, Kurniawan, dkk. 2018. Bentuk Seni Pertunjukan Ronggeng Pasaman di Kabupaten Pasaman di Sumatra Barat. (Jurnal). Padang Panjang: Program Pascasarjana ISI Padang Panjang.

Gayatri, Satya. 2010. "Sistem Formula dan Fungsi dalam Sastra Lisan Ronggeng Pasaman". (Jurnal). Padang: Sastra 
Daerah FIB Andalas University.

Gusmanto, Rico. 2016. "Akultrasi Minangkabau, Jawa, dan Mandailiang dalam Kesenian Ronggiang Pasaman di Kabupaten Pasaman Barat Provinsi Sumatra Barat". (Laporan Penelitian). Padang Panjang: Garak jo Garik Jurnal Pengkajian dan Penciptaan Seni.

Hutomo, Suripan Sadi. 1991. Mutiara Yang Terlupan. Komisariat Jawa Timur: Hiski.

Mad'hattari, dkk. 2019. Hibriditas Ronggeng di Minangkabau. (Jurnal). Padang Panjang: Program Pascasarjana ISI Padangpanjang.

Meigalia, Eka. 2013. "Ronggeng di Minangkabau". (Jurnal). Padang: Andalas University.

Mustika, Nuzula dkk. 2014. "Bentuk Penyajian Ronggeng dalam Upacara Adat Turun Mandi Anak di Muaro Kiawai Kecamatan Gunung Tuleh Kabupaten asaman Barat". (Jurnal). Padang: University Negeri Padang.

Pratama, Gema. 2015. "Kesenian Ronggeng Pasaman di Kenagarian Simpang Tonang, Kecamatan Dua koto, Kabupaten Pasaman (Studi Kasus Perubahan Ronggeng Pasaman)". (Jurnal). Baru Pekanbaru: Riau University.

Pudentia. 2007. Hakikat Kelisanan Dalam Melayu Mak Yong. Jakarta: FIB-UI.

Taum, Yosep Yapi. 2011. Studi Sastra Lisan. Yogyakarta: Lamarela.

Saydam, Gouzali. 2004. Kamus Lengkap Bahasa Minang (Minang-Indonesia). Sumatra Barat: Pusat Pengkajian Islam dan Minangkabau.

Sukatman. 2009. "Butir- Butir Tradisi Lisan Indonesia" Dalam Harsen Novan. Dikia Rabano Di Kecamatan Pauh Kota Padang. Padang: Universitas Andalas.

Yanti, Yasri Fitri. 2009. "Pengarsipan Dan Klarifikasi Teka-Teki Berdasarkan Bentuk Sebagai Cerminan Budaya Nagari Koto Gaek Guguak Kecamatan Gunuang Talang Kabupaten Solok. (skripsi). Padang: Universitas Andalas.

Zuriati. Ronggeng Pasaman. http://zuriati.wordpress.com. Diunduh Rabu, 27 November 2019 pukul 11.00 WIB. 